\title{
THE INNOVATIVE IMPACT OF INSURANCE FOR ECONOMIC GROWTH: THE EVIDENCE FROM NEW EU MEMBER STATES
}

\author{
Hristo Kondovski ${ }^{1}$
}

Received 21. 10. 2021.

Sent to review 25. 10. 2021.

Accepted 09. 12. 2021.

\section{Original Article}

${ }^{1}$ Executive Director of SN Insurance Broker AD Bitola, Northern Macedonia

Corresponding Author:

Hristo Kondovski

Email: hristo.kondovski@snbroker.mk

JEL Classification:

C10; G22; O40

Doi: 10.2478/eoik-2021-0024

UDK: 005.591.5:[330.341.4:338.45

\begin{abstract}
Insurance market activity, both as a financial intermediary and a provider of risk transfer and indemnification, may contribute to economic growth by allowing different risks to be managed more efficiently and by mobilizing domestic savings. During the last decade, there has been faster growth in insurance market activity, particularly in emerging markets given the process of liberalization and financial integration, which raises questions about its impact on economic growth.The aim of this paper is to examine relationship between insurance sector development and economic in 11 new EU member states from CentralandEasternEurope, using annual data fortheperiod 1999-2018. We apply dynamic and fully modified ordinary least squares to estimate the relationship between the variables. The results of our study indicate there are a positive and a significant relationship between insurance, measured through penetration, and economic growth Thus, functions of insurance companies - providing means of risk management and performing mobilization and allocation of resources - are important for economic growth and is in line with previous studies and with our hypothesis These results could be useful for regional governments that seek to improve economic growth as they suggest the need for implementation of stimulative policies for the development of insurance industry
\end{abstract}

Keywords: insurance, economic growth, 11 new EU member states

\section{INTRODUCTION}

Over the last decade considerable attention has been paid to evaluating the relation ship between financial development and economic growth.According to the finance-growth nexus theory financial development promotes economic growth through channels of marginal productivity of capital, efficiency of channeling saving to investment, saving rate and technological innovation (Levine, 1997). Affecting economic growth through the channels is realized by functions of financial intermediaries. Financial intermediaries have an advantage over direct financing in economies of scale that result from costs shared. Additionally, large amount of funds enables financial intermediaries to be more easily diversified than individual economic units. The reduction in transaction costs, as the main function of financial intermediaries, was first introduced by 3 . According to the traditional theory of financial intermediation the real-world market is characterized by frictions that include transaction costs and asymmetric information.

A numerous empirical studies confirm that financial intermediation plays a growth-supporting 
role. Empirical research conducted by King and Levine (1993) about the impact of the banking sector on the development of the economy showed that the banking sector contributes to economic growth and that there is a positive causal relationship between banking sector and economic growth (Levine, 1997). Among financial intermediaries, in performing functions of financial system insurance companies is growing in importance. Like other financial institutions such as banking and the stock marketthe importance of insurance,is crutial for the sustainable economic growth of any country Peleckiene et al (2019). The importance of insurance cannot be denied because of its economic outlook, for instance, insurance spending is $6.23 \%$ of World's GDP (Sigma Swiss-Re, 2016). More precisely, insurance spending for developed countries is around $8-11 \%$ whereas it is $2-4 \%$ for developing countries. However, statistics revealed a significant reduction, from $88-$ $67 \%$, in the share of developed countries premium since 2005 and an upward shift in insurance premiums for emerging and developing countries (Swiss-Re, 2016). But, unlike other financial activities there are relatively small number of empirical studieswho have investigate the impact of the insurance industry on economic growth. Although banking, insurance, and securities markets are closely related, insurance performs some what different economic functions Brainard (2008). Bearing this in mind it requires particular attention and analysis. The relationship between the insurance sector and economic growth hasreceived increasing interest among scholars in recent studies. The research of the insurance-growth nexus has held an inconclusive explanation about the association between these variables Peleckiene et al (2019). Researchers have debated over the nature of causality,whether insurance development causes economic growth or economic growth leadsinsurance sector or both variables cause each other. A number of questions must be answered about how the growth of economy associates with the insurance industry. According to Cristea et al (2014), insurance becomes a major component in certain countries. The contribution of insurance to GDP of the economies being over $10 \%$ in some European countries, such as The Netherlands, the UK and Finland, has shown that it is even higher as the economic development is higher. Even though the potential contribution of the insurance sector on economic growth has been recognised, the assessment of the insurance-growth nexushas not been studied as much as that of the banking sector (Cristea et al., 2014).Moreover, the results of insurance-growth studies have varied across the countries dueto the levels of socio-economic development, nature of economic structures, financialmarkets development, and the period analysed and methodology applied. What is moreimportant, studies examining the relationship between insurance and economic growthhave been scarce. According to (Zou and Adams, 2006) property insurance can facilitate bank intermediation, for example by partialprotection that would affect the reduction of credit risk to promoting higher levels of lending In terms of impact on the stock market, the development of insurance, especially life insurance, may contribute to its development through investment funds (savings) in stocks and bonds (USAID 2006). In this context, the main objective of this paper is to examine the impact of the insurance industry on economic growth. Our sample consists $11 \mathrm{new}$ EU member states(Bulgaria, Croatia, Czech Republic, Estonia, Hungary, Latvia, Lithuania, Poland, Romania, Slovak Republic and Slovenia), over the 1999-2018 period. As proxy of insurance sector development we usingpenetration of insurance.We apply Fully Modified Ordinary Least Squares (FMOLS) and the Dynamic Ordinary Least Squares (DOLS) estimation techniques The paper is organized as follows. Section 2 briefly reviews the existing cross-country studies of who has investigate the relationship between insurance sector and economic growth. Section 3 introduces the empirical methodology and data. The results are presented and interpreted in section 4 . Finally, section 5 synthesizes paper findings and offers policy-relevant recommendations.

\section{LITERATURE REVIEW}

In this section we present a brief sublimate of empirical literature concerning the relationship between insurance sector and economic growth. When it is noted that often the relationship between 
insurance sector and economic growth is explored in panel context (studies of groups of countries). Webb, Grace and Skipper (2002) examine whether banks, life and nonlife insurers individually and collectively contribute to economic growth, They use cross-country data for 55 countries for the period 1980-1996 year. As a measure of the impact of insurance on economic development used by the authors is insurance penetration (insurance premium to GDP) for both life and non-life insurance, respectively. Research has shown that the penetration of life insurance is significantly positive correlated with economic growth, and that relationship is mutual. In addition, they stated that there is no link between economic development and non-life insurance

Empirical study of the Arena (2008) on the relationship between insurance and economic growth includes 56 countries (as developed and developing countries) for the period 1976-2004 year. Insurance premiums are used as proxies of total and life and non-life insurance activity separately. Results show positive and significant effect of life and non-life insurance on economic growth. Impact of life insurance on economic growth is the high only for developed countries. In the case of nonlife insurance, its impact is significant in both developed and developing countries, but this impact is greater in developed countries than in the developing countries. Haiss and Sumegi (2008) apply panel data analysis over the period of 1992-2004 for 29 OECDcountries to explore the relationship between insurance and economic growth. They found that insurancedifferently affects economic growth of countries, for example, life insurance has becomemore significant for 15 OECD countries while non-life insurance has the same for rest of the 14countries. Kjosevski (2011) wasinvestigated the relationship of insurance and economic growth for the Macedonia using the multiple regression models. Results highlighted that aggregate insurance industry and non-life insurance has a positive and significant effect on economic growth of Macedonia for the period 1995-2010. On the other hand, life insurance has significant but negatively affecting the economic growth of Macedonia. The author claimed that astrong banking sector (saving substitute and investment channel) could be the possible reason for the negative relationship between life insurance and economic growth for Macedonia. Peleckiene et al (2019) has examined the relationships between insurance and economic growth across the European Union countries He was used annual data over the period of 2004-2015. His research has led to the following broad conclusions: (1) descriptive statistics analysis has shown that the insurance sector development is higher in economically rich countries, such as the UK,Denmark, Finland, Ireland, France and The Netherlands; (2) a positive statistically significant relationship between insurance penetration and economic growth has been detected in Luxembourg, Denmark, The Netherlands and Finland. Besides, a negative statistically significant relationship has been identified in Austria, Belgium, Malta, Estonia and Slovakia; (3) Granger test has shown unidirectional causality running from GDP to insurance in Luxembourg and Finland; and unidirectional causality from insurance to GDP in The Netherlands, Malta and Estonia. The case of Austria has shown bidirectional causality between the variables. The analysis has presented the absence of causality between insurance and economic growth in Slovakia Although there are strong theoretical explanations for the positive impact of the insurance sector on economic growth, the results of empirical research conducted to date are different. However, we can say that the number of empirical studies is relatively small, especially compared to those of bank contribution to economic growth Levine (1997), Dawson (2008). Moreover, the impact of insurance on the growth of the economy in transition countries is examined separately, as part of a study (Haiss and Sümegi, 2008). Based on the analysis of theoretical foundations and empirical research will further focus on empirical analysis.

\section{DATA AND METHODOLOGY}

Our study dataset consists of a sample of 11 new EU members states (NMS) from Central, Eastern and Southeastern Europe (Bulgaria, Croatia, the Czech Republic, Estonia, Hungary, Latvia, Lithuania, Poland, Romania, the Slovak Republic and Slovenia) using annual data for the 
period 1999-2018. The selection of countries is based on their deepening political, economic, and institutional integration with the European Union (EU). The core determinants selected in our model have been used in the academic literature (Kjosevski 2011, Peleckiene et all 2019). The internationally comparable and reliable data comes from a variety of providers: Sigma, Swiss Re Economic Research \& Consulting, Swiss Re, Zurich and national insurance associations, IMF's International Financial Statistics and Monetary and Financial Statistics database, European Central Bank's (ECB) Statistical Data and the World Bank's World Development Indicators. Based on the theoretical guidance from the literature review, the following explanatory variables will be used:

1. Macroeconomic determinants:Exports of goods and services (\% of GDP) (export) General government final consumption expenditure (annual \% growth) (consum)Gross capital formation (\% of GDP) (gcf)the inflation rate (infl);

2. Financial determinants: insurance companies' penetration as a percent of GDP (penetra), Bank credit to private sector (\% of GDP), (bcps) and a stock market capitalisation $(\mathrm{smc})$,

Our analysis focuses on the impact of insurance on economic growth and interection ofinsurance in promoting economic growth. As insurers collect premiums for their risk transfer and indemnification services, insurance premiums are used as a standard measure of insurance market development in insurance literature. However, some researchers use total premiums (e.g. Ward and Zurbruegg, 2000) while others use penetration or dentisity (e.g. Webb, Grace and Skipper, 2002; Haiss and Sumegi, 2008; Arena, 2008 Peleckiene et al. 2019). as a measure of development of insurance. In this study we will follow Peleckiene et al. (2019) and as a measure of insurance growth we will used insurance penetration. We hypothesise positive impact of insurance penetration on economic growth. The next two are also financial variables - banking and stock market development. In the literature many studies (Levine, 1999; Levine and Zervos, 1998; Beck and Levine, 2004) have showed that better developed financial systems have positive effect on economic growth. According to the Arena (2008) inconsitencies exist regarding the complementarity and supplementarity effect between banks and capital market development and thus their conjoint effect on economic growth. Furthemore some researchers use only the effect of banking (Ward and Zurbruegg, 2000; Webb, Grace and Skipper, 2002, Adams et al., 2009) while others examine the effect of capital market development as well (Arena, 2008). Bearing this in mind we assume that both banking and capital markets are important for economic growth. Following mentioned previous studies in insurance related literature and banking related literature (e.g. King and Levine, 1993; Beck and Levine, 2004) we use the ratio of bank credit to private sector in relation to GDP (private credit). Following Arena (2008) as a proxy for capital market development effect on economic growth we use stock capitalization divided by GDP. For these two variables we expect to be positively related to economic growth. The next variable is investment. We follow common Kjosevski (2011) and we used gross capital formation (formerly gross domestic investment) as a proxy for investment. Gross capital formation consists of outlays on additions to the fixed assets of the economy plus the net changes in the level of inventors. The expected sign of the coefficient is positive. The following control variable used in our research as a determinant of economic growth is exports of goods and services in relation to GDP. Empirical studies have confirmed that export positively affect economic growth. This variable is also present as additional explanatory variable in insurance related literature that examines how insurance market development affects economic growth (Webb, Grace and Skipper, 2002; Arena, 2008). For this variable we expect to be positively related to economic growth. The government has an important role for the establishment of framework for private sector development in every economy. However, numerious theoretical and empirical research suggest that the larger government consumption the less developed will be financial system, and especially insurance industry. For example, Beenstock, Dickinson and 
Khajurja (1986) found that life insurance premiums vary inversely with social security coverage. If government provide indemnification for property losses, disability, retirement and health care, individuals will have less incentives to purchase insurance (Skipper and Kwon, 2007), the fact that was especially emphasised during the communist era in Eastern Europe (Dorfman, 2008). Also, greater government consumption is generaly considered to decrease the efficiency of investments as its investments are directed by political and social considerations (Webb, Grace and Skipper, 2002; Dorfman, 2008). Therefore, general goverment consumption is usually used as a control variable when depicting economic growth in both banking related literature (King and Levine, 1993; Levine, 1998; Berthelemy and Varoudakis, 1996; Ahlin and Pang, 2008) and insurance related literature (Ward and Zurbruegg, 2000; Webb, Grace and Skipper, 2002; Arena, 2008). We measure government expenditure as a ratio of general goverment expenditures to GDP. We hypothesise negative relationship between government expenditures and economic growth. The last variable used to control for other influences on economic growth is the inflation rate. It is used to account for monetary discipline. It is expressed by the GDP deflator (annual percentage). With this variable, we expect a negative correlation with economic growth. 
Table 1. Descriptive statistics.

\begin{tabular}{|l|c|c|c|c|c|c|c|}
\hline & GDPG & PENETRA & BCPS & STOC & EXPORT & INVES & INF \\
\hline Mean & 3.249 & 2.813 & 47.41 & 5.281 & 56.36 & 24.95 & 4.030 \\
\hline Median & 3.604 & 2.7 & 47.26 & 2.416 & 57.03 & 24.58 & 2.831 \\
\hline Maximum & 11.888 & 6 & 100.7 & 33.78 & 96.21 & 41.89 & 45.80 \\
\hline Minimum & -14.81 & 0.71 & 0.186 & 0.020 & 21.58 & 12.65 & -1.544 \\
\hline Observations & 220 & 213 & 170 & 173 & 219 & 219 & 220 \\
\hline
\end{tabular}

Source: Authors' calculations.

The heterogeneity in economic growth rates $(g d p g)$ is remarkable: the annual GDP growth varies from almost $12 \%$ to nearly $-15 \%$. The insurance penetration also displays large differences: it ranges from a minimum of $0.7 \%$ of GDP, up to a maximum of $6 \%$ of GDP. Also there are large differences in other selected determinants such as stoc market capitalization and inflation. The empirical strategy in this study is based on a panel data analysis. According to Maddala (2001), one of the main advantages of panel data estimation is that it allows for testing and adjustment of the assumptions that are implicit in the cross-sectional analysis. Hsiao(1986) adds other benefits of conducting a panel data analysis: (1) panel data suggest that individual countries are heterogeneous; (2) panel data give more information, more variability, less collinearity among other variables, greater degrees of freedom and higher efficiency; (3) panel data can capture and measure effects that are not detectable by cross-sectional time-series analysis, as well as provide a test platform for more complicated behavioral models. The model is a linear regression model linking indicators that measure the growth of the GDPG in the countries under investigation with several potentially relevant determinants, as depicted by Equation (1).

$$
G D P G_{i t}=\beta_{l} P E N_{i, t}+\beta_{j} D E T_{j, i, t}+u_{i, t}
$$

where $i$ refers to the country ( $i=1-11)$; $t$ refers to time periods (years) $(t=1-19) ; G D P G_{i, j}$ is the dependent variable, i.e. a gdp growth; PEN is a penetration of insurance $\beta_{1}$ is the coefficients of this explanatory variable, $D E T_{i, j}$ is a vector of potential driving forces of GDP growth; $\beta_{j}$ are the coefficients of these explanatory variables, and $u_{i, t}$ are the idiosyncratic (observation-specific) errors. Before proceeding to the econometric method, we need to verify the stationarity of the variables selected. In this paper, we performed a panel analysis and applied panel unit root tests the Im,Pesaran and Shin- (IPS) test (2003) and two alternatives of a Fisher-type test (Augmented Dickey-Fuller (ADF) and Perron (PP) test), as outlined by Maddala and Wu (1999). These tests allow for the deterministic and dynamic effects differing across the panel members. In this paper, a $10 \%$ level of importance was applied as a critical value for determining whether the time series is stationary. According to Baltagi (2001), the Fisher-type tests have more advantages, because: (1) the cross-sectional dimension can be either finite or infinite; (2) each group can have nonstochastic and stochastic components; and (3) the time-series dimension can vary for each crosssection. An additional advantage is that, unlike the IPS test, it does not require a balanced panel and allows for the use of different lag lengths in the individual ADF regressions. In our study, we prefer the Fisher-type tests, but we also report the results of the IPS tests to provide an additional check for robustness. Furthermore, to estimate the existence of a long-run relationship between the dependent variable and the explanatory variables, we must test the cointegration equations in the panel. In this paper, we will use two cointegration tests - Pedroni (1999) and Kao (1999) - to test the null hypothesis of no cointegration between the selected determinants. Having established the cointegration tests, the next step is to estimate the long-term relationship between the variables. 
The literature proposes different estimation methods for panel cointegration models. In this paper, we will be using the Fully Modified Ordinary Least Square (FMOLS) and the Dynamic Ordinary Least Squares (DOLS) estimators. We choose these methods for several reasons. Firstly, the OLS estimator is a biased and inconsistent estimator when applied to a cointegrated panel. On the other hand, DOLS and FMOLS take care of both small sample bias and endogeneity bias by taking the leads and lags of the first-differenced regressors (Kao, and Chiang, 2000). Secondly, for panels that have a larger time dimension ( $T$ ), the dynamic estimator of the Generalized Method of Moments (GMM) is not very effective, as it is more applicable when the number of the cross-sectional units is higher than the time periods (Roodman, 2009). In this research, the time dimension ( $T=19)$ is much greater than the cross-sectional dimension $(N=11)$. Thirdly, these estimators allow for a greater flexibility in the presence of heterogeneity in the examined cointegrated vectors (Pedroni, 1999; 2001). Given that this study meets the number-of-observations criterion under all three models, we expect the results to be asymptotically equivalent to authenticate the robustness of the results.

With a view to explain the idea of FMOLS estimator, we refer to the following fixed-effects model:

$$
G D P G_{i, t}=\alpha_{i}+x_{i, t}^{\prime} \beta+u_{i, t}
$$

where, $i(=1,2, \ldots, N)$, and $t(=1,2, \ldots, T)$ indexes being the cross-sectional units and time series units, respectively, GDPG ${ }_{, t}$ is the GDP growth (an I(1) process), $\beta$ is the vector of parameters, $\alpha_{i}$ are intercepts and $u_{i, t}$ are the stationary disturbance terms. Here, $x_{i, t}$ are assumed to be the vector of explanatory variables, which are I(1) for all cross-section units. It is assumed that it follows an autoregressive process in the following form:

$$
x_{i, t}=x_{i, t-1}+\varepsilon_{i, t}
$$

with an innovation vector: $w_{i, t}=\left(u_{i, t}, \varepsilon_{i, t}\right)$

Given that $w_{i, t}=\left(u_{i, t}, \varepsilon_{i, t}\right) \sim I(0)$, the variables are said to be cointegrated for each member of the panel with the cointegrating vector $\beta$. The asymptotic distribution of the OLS estimator is the condition for the long run covariance matrix of the innovation vector. The FMOLS estimator is derived by making an endogeneity correction (by modifying the variable $G D P G_{i, t}$ ) and a serial correlation correction (by modifying the long run covariance of the innovation vector, $w_{i, t}$ ). The resulting final estimator is expressed as follows:

$$
\beta_{F M O L S}=\left[\sum_{i=1}^{N} \sum_{t=1}^{T}\left(x_{i}-\bar{x}\left(x_{i}-\bar{x}_{i}\right)\right]^{-1} *\left[\sum_{i=1}^{N}\left(\sum_{i=1}^{T}\left(x_{i t}-\bar{x}\right) G D P G_{i}-T \hat{\Delta}_{\varepsilon U}\right)\right]^{-1}\right.
$$

The DOLS estimator has been extended to panel analysis by Kao and Chiang (2000), who developed finite sample properties of the OLS, DOLS, and Pedroni's FMOLS. The DOLS estimator in a panel case environment is obtained by running the following regression:

$$
G D P G_{i, t}=\alpha_{i}+\beta_{i} x_{i, t}+\sum_{k=-p_{1}}^{p_{2}} \delta_{k} \Delta G D P G_{i, t-k}+\sum_{k-q_{1}}^{q_{2}} \lambda_{k} \Delta x_{i, t-k}+u_{i, t}
$$

where $p$ and $q$ denote the numbers of leads and lags typically chosen using certain information criterion (e.g., Akaike, Hansen). 
Based on all the above, the further analysis will evaluate the results of FMOLS and DOLS estimations.

\section{EMPIRICAL RESULTS}

In this section, we present the results of the econometric analysis of the impact of insurance on economic growth in the selected new EU member states. The first step of our empirical analysis was to perform panel unit root tests. As already mentioned in the previous section, we applied panel-IPS unit root tests and Fisher-Type tests using ADF and PP-test, as outlined by Maddala and $\mathrm{Wu}$ (1999). These tests are conducted on both levels and first differences for all variables in the model. The all-time series involved contains unit roots according to the IPS test. Furthermore, the panel unit roots tests for ADF and PP also support the hypothesis of a unit root in all variables across countries. Following the traditional null hypothesis of stationarity, the results consistently accept stationarity at first difference and reject stationarity at levels indicating that all series are I(1).

Table 2. Panel unit root tests.

\begin{tabular}{|c|c|c|c|c|c|c|c|}
\hline \multirow[b]{2}{*}{ Variables } & \multicolumn{2}{|c|}{ Im, Pesaran and Shin W-stat } & \multicolumn{2}{|c|}{ ADF-Fisher Chi square } & \multicolumn{2}{|c|}{ PP-Fisher Chi square } & \multirow[b]{2}{*}{ Implication } \\
\hline & $\begin{array}{c}\text { At a } \\
\text { level of }\end{array}$ & $\begin{array}{c}\text { First } \\
\text { differentiation }\end{array}$ & $\begin{array}{c}\text { At a } \\
\text { level of }\end{array}$ & $\begin{array}{c}\text { First } \\
\text { differentiation }\end{array}$ & $\begin{array}{c}\text { At a } \\
\text { level of }\end{array}$ & $\begin{array}{c}\text { First } \\
\text { differentiation }\end{array}$ & \\
\hline GDPG & 1.37 & $-3.79^{* * *}$ & 24.32 & $51.09^{* * *}$ & 8.96 & $63.49^{* * *}$ & $\mathrm{I}(1)$ \\
\hline PEN & 1.13 & $-3.91^{\star * *}$ & 14.46 & $54.19^{\star * *}$ & 21.74 & $118.6^{\star * *}$ & $\mathrm{I}(1)$ \\
\hline BCPS & -0.87 & $-4.26^{* * *}$ & 27.81 & $53.45^{\star * *}$ & 64.38 & $78.49^{\star * *}$ & $\mathrm{I}(1)$ \\
\hline STOCK & -1.50 & $-4.79^{\star * *}$ & 29.14 & $68.46^{* * *}$ & 30.44 & $129.0^{* * *}$ & $\mathrm{I}(1)$ \\
\hline EXPORT & 2.69 & $-5.79^{\star * *}$ & 6.05 & $74.3^{* * *}$ & 7.96 & $117.8^{\star \star \star}$ & $\mathrm{I}(1)$ \\
\hline INV & -0.25 & $-7.62^{\star * *}$ & 39.36 & $97.30^{\star * *}$ & 26.42 & $131.5^{\star * *}$ & $\mathrm{I}(1)$ \\
\hline INF & 0.24 & $-5.33^{* * *}$ & 28.35 & $70.75^{\star * *}$ & 7.24 & $47.09^{\star * *}$ & $\mathrm{I}(1)$ \\
\hline
\end{tabular}

${ }^{*},{ }^{* *}$ and ${ }^{* * *}$ indicate that the test statistic is significant at the $10 \%, 5 \%$ or $1 \%$ level.

Source: Authors' calculations.

Following the panel unit root tests results for all series of interest, the null hypothesis of a unit root cannot be rejected. Since the null hypothesis of a unit root holds for all series of interest, we continued with panel cointegration tests as the next step. 
Table 3. Results of Pedroni’s and Kao's panel cointegration tests.

\begin{tabular}{|l|c|}
\hline \multirow{2}{*}{ Model } & 11 EU member countries \\
\cline { 2 - 2 } & Stat \\
\hline Panel v-Statistic & -1.45 \\
\hline Panel rho-Statistic & 2.76 \\
\hline Panel PP-Statistic & $-1.73^{\star * *}$ \\
\hline Panel ADF-Statistic & $2.74^{* * *}$ \\
\hline Group rho-Statistic & 3.39 \\
\hline Group PP-Statistic & $-12.1^{\star * *}$ \\
\hline Group ADF-Statistic & $-11.7^{\star * *}$ \\
\hline Kao Residual Cointegration Test $(p$-value $)$ & 0.000 \\
\hline
\end{tabular}

Source: Authors' calculations.

As presented in Table 6 , the majority of Pedroni's $(1999,2001)$ tests indicate that there is a cointegration relationship for all four models. The Kao's (1999) test in Table 6 also indicates a cointegration relationship in all models. This also implies the existence of a long-run relationship among the variables in all cases. In line with the purpose of this study, once the properties of all variables are co-integrated, the next step is to implement the FMOLS and DOLS tests in order to investigate the long-run linkage among the insurance penetration and economic growth.

Table 4. Estimation results.

\begin{tabular}{|c|c|c|c|c|}
\hline \multirow{2}{*}{ Variables } & \multicolumn{4}{|c|}{$\begin{array}{l}\text { Total } \\
\text { (11 NMS) }\end{array}$} \\
\hline & FMOLS & & DOLS & \\
\hline PEN & $0.16^{\star * \star}$ & $(0.14)$ & $0.26^{* * *}$ & $(0.31)$ \\
\hline BCPS & $0.09^{* *}$ & $(0.08)$ & $0.08^{\star \star \star}$ & $(0.01)$ \\
\hline STOCK & 0.01 & $(0.02)$ & 0.04 & $(0.05)$ \\
\hline EXPORT & 0.03 & $(0.01)$ & 0.09 & $(0.02)$ \\
\hline INV & $0.25^{\star * \star}$ & $(0.02)$ & $0.30^{\star * *}$ & $(0.05)$ \\
\hline INF & -0.04 & $(0.03)$ & $-0.19^{\star \star *}$ & $(0.05)$ \\
\hline
\end{tabular}

Note: ${ }^{*}{ }^{* *}$ and ${ }^{* * *}$ indicate that the test statistic is significant at the $10 \%, 5 \%$ or $1 \%$ level.

Standard errors in parentheses.

From the resultsof the analysis from the methodswe can conclude that the growth insurance penetration positively affects economic growth, with statistical significance of $1 \%$, The results of the analysis showed that the financial sector, in this case the insurance sector is not only a passive follower of economic growth, but its determinant. The contribution of insurance to the economic growth achieved by its participation in the execution of the given functions of financial system, and primarily those relating to risk management, accumulation and allocation of monetary funds. Namely, the organization of communities at risk of the principle of reciprocity, ie by 
reducing transaction costs and information asymmetry in the transmission of financial resources, insurers limit affecting productivity of capital and technological innovations in the rate of saving. Additionally, increasing the efficiency of financial intermediation can reduce the cost of mediation or part of the savings used to settle of that cost, further of forementioned features would make a positive impact on economic growth. In this contex also the results from BCPS show positively and statistically significant effect on economic growth. From the other determinants only investment was significant in both methods, while inflation was significant negative effect only when we used DOLS method. 


\section{CONCLUSION}

Using dynamic and fully modified ordinary least squares we examined whether insurance, contribute to economic growth in 11 new EU member states from Central and Eastern Europe, using annual data fortheperiod 1999-2018. According to our results we find evidence for a growthsupporting role of insurance. Namelly insurance positively and significantly affects economic growth insurance development promotes economic growth. Thus, functions of insurance companies - providing means of risk management and performing mobilization and allocation of resources - are important for economic growth and is in line with previous studies and with our hypothesis. The findings from this study could be suggestive for insurance sector's policy makers. The key is to implement the policies that are going to provide institutional improvements, encourage competition, and contribute to increasing efficiency, especially in risk management, and product development of insurance companies. In the future research of insurance-growth, besides insurance penetration, insurance development could be measured by annual insurance premium, insurance density and by the assets of insurance companies. Also, research of interrelationship between insurance and nonfinancial sectors of the economy in the promotion of economic growth should be of interest for further research. Finally, the results from panel study such as ours might hide actual results for specific countries. Therefore, in addition to longer time periods, further research of the issue of how insurance market development promotes economic growth should focus on per country analyses. 


\section{REFERENCES}

Adams, M., Andersson, J., Andersson L-F. and Lindmark, M. (2009) "Commercial banking, insurance and economic growth in Sweden between 1830and 1998", Accounting, Business \& Financial History, Vol. 19, No. 1: 21-38. https://doi.org/10.1080/09585200802667139

Ahlin, C. and Pang, J.(2008) "Are financial development and corruption control substitutes in promoting growth?”. Journal of Development Economics, Vol. 86, No. 2: 414-433. https://doi.org/10.1016/j.jdeveco.2007.07.002

Arena, M. (2008) "Does Insurance Market Activity Promote EconomicGrowth? A Cross-Country Study for Industrialized and Developing Countries", Journal of Risk and Insurance, Vol. 75, No. 4: 921-946.

Baltagi, B (2001)."Econometric Analysis of Panel Data", 2nd ed., John Wiley and Sons,

Brainard, L. (2008). What is the role of insurance in economic development? Zurich Financial Services, Zurich,

Berthelemy, J. C. and Varoudakis, A. (1996) Economic Growth,Convergence Clubs, and the Role of Financial Development”. Oxford Economic Papers, New Series, Vol. 48, No. 2: 300-328.

Beck, T. and Levine, R. (2004) "Stock markets, banks, and growth:Panel evidence, Journal of Banking \& Finance, Vol. 28, No. 3: 423-442. https://doi.org/10.1016/S0378-4266(02)00408-9

Beenstock, M., Dickinson, G. and Khajuria, S. (1986)“TheDetermination of Life Premiums: An International Cross-Section analysis” 1970-1981, Insurance, Mathematics and Economics, Vol. 5, No. 4: 261-270

Cristea, M., Marcu, N., \& Carstina, S. (2014)“The relationship between insurance and economic growth in Romania compared to the main results in Europe-A theoretical and empirical analysis". Procedia Economics and Finance, 8: 226-235. doi:10.1016/S2212-5671(14)00085-9

Dawson, P.J. (2008) "Financial development and economic growth in developing countries". Progress in Development Studies. https://doi.org/10.1177/146499340800800402

Din S. M. Abu-Bakar, A Regupathi, A (2017) "Does insurance promote economic growth: A comparative study of developed and emerging/ developing economies Cogent Economics \& Finance. https://doi.org/10.1080/23322039.2017.1390029

Dorfman, M. S. (2008), "Introduction to Risk Management and Insurance”, Upper Saddle River, NJ: Pearson Education, Inc.

Haiss, P. and Sümegi, K. (2008) "The relationship between insurance and economic growth inEurope: a theoretical and empirical analysis", Empirica, 35 (4):405-431 doi 10.1007/s10663-008-9075-2

Grace, M. F., Rebello M. J., (1993) “Financing and the Demand for Corporate Insurance”, The Geneva Risk and Insurance Review, Palgrave Macmillan Journals, vol. 18(2):147-171,

Kao, C, and Min-Hsien C, 2000. "On the estimation and inference of a cointegrated regression in panel data",Advances in Econometrics 15:179-222

Kao, C (1999)“Spurious regression and residual-based tests for cointegration in panel data, Journal of Econometrics Volume 90, Issue 1: 1-44

King, R and Levine, R. (1993) "Finance and Growth. Schumpeter Might Be Right. Policy Research Working papers, 1083.

Levine, R. (1997) "Financial Development and Economic Growth: Views and Agenda". Journal of Economic Literature, Vol. XXXV(6), pp. 688-726.

Maddala, G. S, and Wu, Shaowen (1999)"A comparative study of unit root tests with panel data and a new simple test".Oxford Bulletin of Economics and Statistics, 61(S1): 631-652 Maddala, G.S. 2001.Introduction to Econometrics. 3rd Edition, Wiley, New York.

USAID. (2006) "Assessment on How Strengthening the Insurance Industry in Developing Countries Contributes to Economic Growth", United States Agency for International Development 
Pedroni, P.(1999) "Critical values for cointegration tests in heterogeneous panels with multiple regressors",Oxford Bulletin of Economics and Statistics 61: 653-670.

Pedroni, P. 2001. "Purchasing power parity tests in cointegrated panels",Review of Economics and S tatistics 83: 727-731.

Peleckienė, K Peleckis, G Dudzevičiūtė \& Kęstutis K. (2019) The relationship between insurance and economic growth: evidence from the European Union countries"Economic ResearchEkonomska Istraživanja, 32:1, 1138-1151, https://doi.org/10.1080/1331677X.2019.1588765

Roodman, D., (2009) How to do xtabond2: An introduction to difference and system GMM in Stata "Stata Journal",Vol. 9, Issue 1: 86-136,

Sigma Swiss-Re, (2016) Reporting Home - Swiss Re Annual Report 2016

Skipper, H. D. and Kwon, W. J. (2007) "Risk Management and Insurance: Perspectives in a Global Economy”, Oxford: Blackwell Publishing, Ltd

Kjosevski, J.(2011) "Impact of insurance on Economic growth: The Case of Republic of Macedonia," European Journal of Business and Economics, Vol 4 doi: 10.12955/ejbe.v4i0.154

Ward, D and Zurbruegg, R. (2000) "Does Insurance Promote Economic Growth? Evidence fromOECD Countries", The Journal of Risk and Insurance, 67 (4): 489-506

Webb, I., Grace, M.F. and Skipper, H. (2002) "The effect of banking and insurance on thegrowth of capital and output," Georgia State University working paper

Zou, H., Adams, M. B.(2006) “The Corporate Purchase of Property Insurance: Chinese Evidence”, $J$ ournal of Financial Intermediation 15(2), pp.156-196 (2): 156 - 196. https://doi.org/10.1016/j.jfi.2004.06.007 